\title{
フォトンファクトリー構造生物ビームラインにおける 自動化に向けた取り組み
}

\author{
高エネルギー加速器研究機構放射光科学研究施設構造生物学研究センター \\ 五十嵐教之, 平木雅彦, 松坦直宏, 山田悠介, 若槻壮市
}

\begin{abstract}
Noriyuki IGARASHI, Masahiko HIRAKI, Naohiro MATSUGAKI, Yusuke YAMADA and Soichi WAKATSUKI: Automation in Structural Biology Beamlines of the Photon Factory
\end{abstract}

The Photon Factory currently operates four synchrotron beamlines for protein crystallography and two more beamlines are scheduled to be constructed in the next years. Over the last years these beamlines have been upgraded and equipped with a fully automated beamline control system based on a robotic sample changer. The current system allows for remote operation, controlled from the user's area, of sample mounting, centering and data collection of pre-frozen crystals mounted in Hampton-type cryo-loops on goniometer head. New intuitive graphical user interfaces have been developed so as to control the complete beamline operation. Furthermore, algorithms for automatic sample centering based on pattern matching and X-ray beam scanning are being developed and combined with newly developed diffraction evaluation programs in order to complete entire automation of the data collection.

\section{1.はじめに}

高エネルギー加速器研究機構放射光科学研究施設 (フォ トンファクトリー) では現在 PF, PF-AR と 2 つの放射光専 用リングを運転している.PFリングは 1982 年に運転を開 始した, 世界的に見てもパイオニア的存在の放射光リング であるが，二度にわたる高輝度化改造および2005 年の直 線部増強化改造を経て, 今でも最新の研究に対応した高性 能な光を供給している．また, PF-ARリングは, 当初ブー スターリングとして使用されてきたが，1987年から放射 光利用が開始され, 日本の挿入光源 $\mathrm{X}$ 線ビームラインの 走りとなった. その後 21 世紀に入り, 放射光専用の高エネ ルギー放射光リングとして生まれ変わった.フォトンファ クトリーの構造生物学研究センターでは, 現在これら 2 種 類の放射光リングに 4 本の構造生物学研究用のビームラ インを運用しているが, それだけでなく構造生物学研究全 体にわたり, タンパク質発現から構造解析まで各プロセス の研究技術の高度化を進めている. 本稿では, その中でも ビームラインの自動化に向けた開発について焦点を絞り 解説していく.

近年, 構造生物学研究において, 生体高分子の原子レベ ルの立体構造の重要度が高まっており, 数多くの生体分子 の構造を簡便にかつ素早く決定するというニーズが非常 に高くなっている. 放射光 $\mathrm{X}$ 線結晶構造解析においては, ビームラインの高輝度化, 検出器の読み出し速度の向上,

日本結晶学会誌 第 49 巻 第 6 号 (2007)
制御装置の高性能化などにより,より短時間でデー夕測定 を行うことができるようになってきている.一方, 測定試 料を実験装置にセットするためには放射線防御のための 実験ハッチへの入退出動作が必要であり, 上記のようなハ イスループットビームラインにおいては, 最も時間と手間 のかかる作業となっている. そこでわれわれは, ビームラ インの高速化・自動制御化とともに, スタンフォード放射 光研究所 (SSRL) の協力の下, 結晶試料を自動で交換す るロボットの開発を行った.1),2) 以下, 回折実験の自動化 を目指した, ビームラインの開発, 試料交換ロボットの開 発, そして制御システム開発, 遠隔実験の実現について述 ベていく.

\section{2. ビームライン}

現在, 構造生物学研究センターでは, ハイスループット ビームライン BL-5A, AR-NW12A, 微小集光ビームライン BL-17A, ${ }^{3)}$ および従来光源ビームライン BL-6A と, 異な る 3 種類のビームラインを全国共同利用実験に公開して おり（表 1)，ユーザーはそれぞれの試料の特性に合わせ て, ビームラインを使い分けることができる. 各ビームラ インの実験ハッチには, コリメーションスリットや高速シ ヤッター, 電動 XYZ ステージ付きの高精度ゴニオメータ, 二次元検出器, 試料交換ロボットが設置されている. 測定 試料はゴニオメータ上にセットされ, X 線位置への駆動は 電動 XYZ ステージで遠隔操作される．ほかの駆動軸もす 
表1 フォトンファクトリーにおける構造生物学研究用ビームライン. (Structural biology beamlines of the Photon Factory.) 現在 4 本のビームラインを運用中. 計画されている2本のうち, BL-1A については設計中.

\begin{tabular}{|c|c|c|c|c|c|}
\hline & BL-5A & BL-6A & BL-17A & NW12A & NE3A \\
\hline 共同利用開始年 & 2004年 & 1987年 & 2006年 & 2003年 & 2009年 \\
\hline 放射光リング名 & \multicolumn{3}{|c|}{$\mathrm{PF}$} & \multicolumn{2}{|c|}{ PF-AR } \\
\hline 光源 & 多極ウィグラー & 偏向電磁石 & $\begin{array}{l}\text { ミニポール } \\
\text { アンジュレータ }\end{array}$ & アシジュレー夕 & アンジュレータ \\
\hline 波長範井 (̊) & $0.7 \sim 1.9$ & $0.9 \sim 1.3$ & $\begin{array}{c}0.95 \sim 1.33 \\
1.6 \sim 2.2\end{array}$ & $0.7 \sim 1.9$ & - \\
\hline エネルギー分解能 $(\Delta \mathrm{E} / \mathrm{E})$ & $2.5 \times 10^{-4}$ & $1.0 \times 10^{3}$ & $2.5 \times 10^{-4}$ & $2.5 \times 10^{-4}$ & $\begin{array}{c}\cdots \\
\cdots\end{array}$ \\
\hline フラックス (光子数@1.0 ̊) & $1.0 \times 10^{11}$ & $1.0 \times 10^{10}$ & $\begin{array}{l}6.6 \times 10^{9}(@ 1.0 \AA), \\
1.3 \times 10^{10}(@ 2.0 \AA)\end{array}$ & $2.0 \times 10^{11}$ & - \\
\hline スリットサイズ $(\mu \mathrm{m})$ & 200 & 100 & 20 & 200 & - \\
\hline 榙出器名 & Quantum315 & Quantum 4R & Quantum270 & Quantum210r & - \\
\hline 型 & CCD & CCD & CCD & CCD & $\cdots$ \\
\hline 検出器の面積 $\left(\mathrm{mm}^{2}\right)$ & $315 \times 315$ & $188 \times 188$ & $270 \times 270$ & $210 \times 210$ & \\
\hline 読み出し時間 (秒) & 1 & 8 & 1.1 & 0.9 & - \\
\hline $\begin{array}{c}\text { 典型的な露光時間 } \\
\text { (1度当たり,秒) }\end{array}$ & 5 & 30 & 5 & 3 & - \\
\hline $\begin{array}{c}\text { 典型的なデー夕収集時間 } \\
\text { (1度振動, 180度範囲) }\end{array}$ & 20分 & 2時間 & 20分 & 14分 & - \\
\hline
\end{tabular}

ベて電動化され, 遠隔操作可能となっている. 特に主要軸 はエンコーダー補完により1ミクロン以内で制御され, 精 緻な位置制御が実現されている.また, ガードスリットや ビームストッパー, 試料観察用照明など試料近傍に配置 される光学ユニットやXAFS 実験用検出器は小さなボッ クス (ファンシーボックスと呼ばれる) 内に収納され, 回 折実験時に自動的にセットされるようになっており，回 折実験の利便性と安定性が図られている. 二次元検出器 はCCD 検出器が設置され, 実験条件に応じてカメラ長や オフセットを変更できるようになっている. ビームライ ンを含むすべての機器は, 後述する STARS モータークラ イアントソフトにより制御されており，ネットワークを 介して集中管理されている. ビームラインの端末にはグ ラフィカルユーザーインタフェースがインストールされ， これらモータークライアントと通信を行いながら回折実 験が進められる.

現在, NW12A や BL-5A より高性能な新ハイスループッ トビームライン PF-AR NE3A の建設準備が開始されてい る. NE3Aは，立体構造を基にした薬剤設計に特化したビ ームラインである.アステラス製薬株式会社からの受託 研究により設計・開発され, 2009 年 4 月に運用を開始す る予定である.ビーム夕イムの一部はアステラス製薬株 式会社により専有的に利用され，残りのビームタイムを 全国共同利用実験に公開する予定である.また, 2007 年度 より開始されたターゲットタンパク研究プログラムの技 術開発研究プロジェクトとして, PFリングにおいて微小 集光ビームライン BL-1A の開発を検討しており, 将来的 には 3 本のハイスループットビームラインと 2 本の微小 集光ビームラインを運用する予定である.これらのビー ムラインでは, 実験装置および制御システムが共通化さ
れるため, 開発作業を効率的に進めることができるだけで なく, 放射光利用者の負担も軽減され, ビームラインの運 用効率の向上が期待される.

\section{3. 試料交換ロボット}

\section{1 試料交換ロボットの開発}

試料交換ロボットの開発にあたり最も重視したことは, フォトンファクトリーが大学共同利用機関法人であると いうことである. ビームラインを国内外の多数の研究者が 利用するため, 標準的な試料ピンを使えること, ロボット を使用せずにマニュアルでも容易に試料交換ができるこ とを考慮した. SPring-8で開発したSPACE ${ }^{8}$ は専用のピン (現在は Hampton Research 社のピンも扱えるよう開発が 進められている）を用いることにより，試料交換の容易さ， 位置決めの正確さを実現しているが, 大多数のユーザーは Hampton Research 社のCrystal Cap を使用しているため, このピンを標準的に扱えることが重要である（現在は SPACE の専用ピンも互換で扱えるように開発を進めてい る).また, ユーザーによってはビームラインで試料を凍 結して実験する場合もあり,マニュアルでの試料交換にす ぐに切り替えることができるようにする必要がある.これ は交換ロボットに不具合が生じた場合にも有用である.こ れらの観点から, フォトンファクトリーでは, 水平多関節 ロボットを用いたSSRLのシステムをべースとして, ビ ームラインに合うように改良することにした。

図 1 に開発したロボットの写真を示す. 2004 年にBL-5A と NW12A に設置し, 動作テストを開始した. その後, 2005 年度に開発専用のロボットを製作, 2006 年度にBL-5A と NW12A でユーザー運用を開始し, BL-17A 用のロボット を製作した. 2007 年度からはすべてのビームラインでユ 


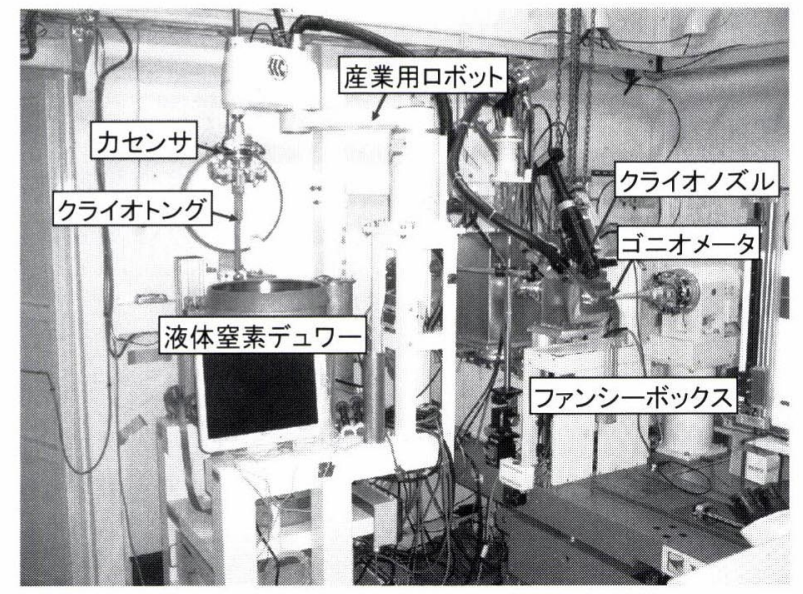

図 1 BL-17A に設置された試料交換ロボット.(Robotic sample exchanger installed at BL-17A.) ロボットは 回折計の横に設置され，ロボットを使用しないと きには退避している。また，ゴニオメータの下に はファンシーボックスが設置されており，同様に 結晶操作中は光学系が退避して, 試料交換時に容 易に作業できるようになっている。

ーザー運用を開始し，いつでも実験ができる状態になっ ている.

ユーザーは標準ピンを使用して結晶をすくい, 金属製 のカセットの中に入れる.カカセットはあらかじめ液体窒 素中で冷やしておき, 結晶をすくったループを凍らせて からカセットに入れることになり，そのためのッール類 も準備されている，カセットは通常凍結試料運搬に使用 されているドライシッパーに入れることができる大きさ である，1個のカセットには, 96 個のピンを挿入すること ができる，カセットは試料交換ロボットに備え付けられ ている液体窒素デュワーに最大 3 個セットすることがで き，合計 288 個のピンを一度にセットすることができる， セットされた標準ピンは, マニュアルでの付け外しと同 様のトングを用いて，極低温に保ったままゴニオメー夕 上に運ばれマウントされる，その後，試料の位置決めを行 ってから回折実験がスタートすることになる。

\section{2 試料交換時間の短縮化}

SSRLで開発されたロボットでは, トングは1つのピン しかもつことができない，そのため，実験が終わったピン を回収し，それから新しいピンをマウントすることにな る.この一連の作業には約 90 秒もの時間がかかり, その 間は次の実験が開始できない状況になる. 今後フォトン カウンティングに近い検出器が利用可能になると, 今ま で以上に試料交換の時間の短縮が必要となり，この時間 は無視できない.そこで, 今までのトングを上下に重ねた ような形状をした，ダブルトングを開発した(図2).4) 上下 のトングはそれぞれ独立に圧空アクチュエータで開閉で きるようになっており, 新しいピンをもったまま古いピン 日本結晶学会誌 第49 巻 第6 号 (2007)

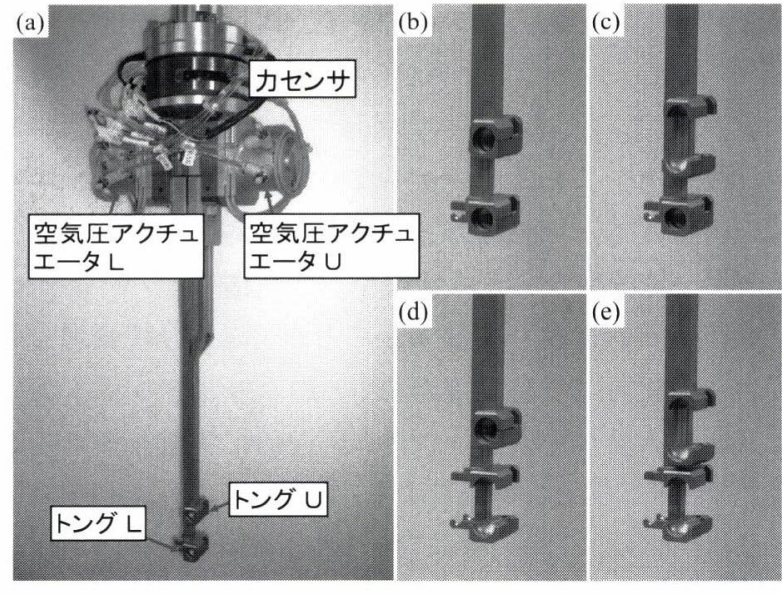

図2開発したダブルトングシステム. (Double tongs system. (a) Overview of the double tongs. (b) - (e) The upper and lower tongs can be opened and closed separately.) (a) 全体図. (b)- (e) 実際の動作.

を回収し，その場ですぐに新しいピンをマウントすること が可能になる。実験の結果, 10 秒以内でピンの交換がで きることが確認された，現在，BL-17Aの試料交換ロボッ 卜に導入し, 試験運用を行っているが, 大きな効力を発揮 している. 今後, ほかのビームラインのロボットにも導入 していく予定である.

\section{4. 制御システムと自動化，遠隔実験の実現}

\subsection{STARS 制御システム}

ビームラインや実験装置, 試料交換ロボットの制御は, 独 自に開発したSTARS 制御システムを用いて行われる。この システムの中核には, フォトンファクトリーで開発された メッセージ配信システム, STARS (Simple Transmission And Retrieval System) が利用されている.5) STARS はも ともとフォトンファクトリーのビームラインインターロ ックシステム用に開発されたもので, TCP/IPソケットを 利用したテキストベースのメッセージ配信システムであ る.ささまざまなテストと改良の結果, 非常に簡便にビーム ライン制御のネットワーク化, 統合化が可能であることが わかり, 構造生物ビームラインの制御システムの核として 導入した. このシステムのデザインとしては, 分散型のシ ステムを採用した. 実験はビームラインに散らばった装置 を, 異なるオペレーティングシステムの下で動作する種々 のコントローラや計算機により協調して行われるため, これらをネットワークで統合して制御する分散型システム は自然で適している.のみならず, 分散システムは, シス テムエンジニアや開発スタッフのグループによってシス テムの異なる部分を同時に開発することを可能にしてい る.システムを各クライアントにモジュール化して扔くこ とで, 将来のソフトウェアのアップグレードおよび修正を 容易に実行できる. STARS 制御システムの場合, STARS 
サーバー, モータークライアント, ユーザークライアン ト, システムクライアントから構成されている. 各クライ アントはSTARS サーバーによって結び付けられ, ユーザ ークライアントと各モータークライアントがコマンドを 送受信することで実験が進められる. 各クライアントは モーター位置やシステム情報を, STARS サーバーのイベ ント配信機能により共有することができ, 接続管理もサ 一バーによって行われるため, どのクライアントも独立 にシステム参加でき, いつでも統合的に実験を進めるこ とができる. 以上の特徵により, 後述するデータベース管 理や自動運転, 遠隔実験についても, 容易にシステムを拡 張していくことが可能となっている.

ユーザークライアントソフト (GUI) は Perl/Tk でコード されており, 基本機能は TCP/IPで通信されるため, ネッ トワーク接続可能な端末であればどこからでも利用可能 となっている.これはプラットフォームに依存しないと いうだけでなく, 例えばビームラインで不具合があった 場合など, サポートスタッフが居室や自宅から直接トラ ブルシュートでき, 素早く対応できるので非常に有用で ある. また, 放射光施設では通常のユーザーは限られたビ 一ムタイムしか使用できず, ビームラインも試料の種類 によって使い分けるため, 直感的なインターフェースの 開発はユーザーにとっても重要である.フォトンファク トリーではそのような観点から, ユーザーフレンドリー で, 実験に必要な機能がわかりやすくまとめられた統合 GUI を開発し運用している (図3)。これとは別に, 膨大な 実験データをデータベースにより統合管理する, 実験管

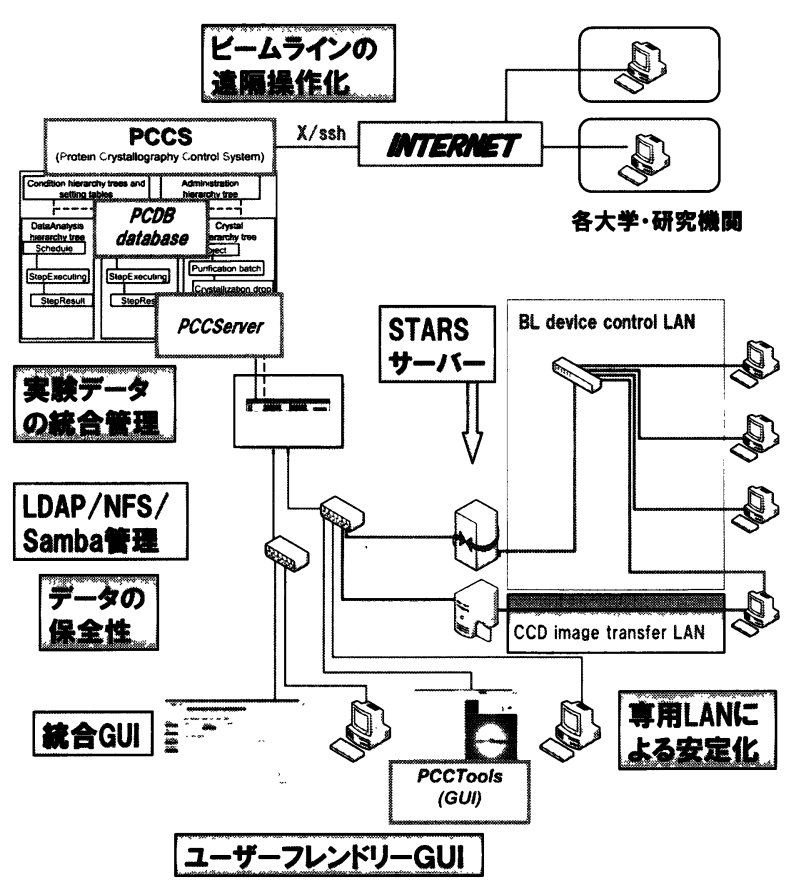

図3 ビームラインネットワーク構成と遠隔操作に向け た取り組み. (PF beamline network configuration.)
理システムPCCS (Protein Crystallographic Control System) も平行して開発しており, テスト運用に入っている.6) PCCS で用いられるインターフェースは, 統合 GUI の経験 やノウハウを活かして開発が進められている. 今後自動運 転や遠隔実験が実現されるときには,このような実験管理 システムが利用されていくであろう.

\section{2 専用ローカルネットワーク}

ビームライン制御においては, 操作の安定性とデータの 保全性が最も重要な課題の1つである. フォトンファクト リーの構造生物ビームラインでは, 装置制御用とデー夕転 送用のローカルネットワークシステムを導入し, STARS システムによるコミュニケーションサーバー方式を採用 することにより,ビームライン制御とユーザー領域とを完 全に区分けし, 安定かつ保全性の高い実験ができる環境を 実現している (図3).ユーザー側からは, STARS サーバー とファイルサーバーのみが制御の空口となり, STARS コ マンドを送信し, 実験データを取得するという構造になっ ている. また, ユーザー領域も構造生物専用の特別なネッ トワークの中にあり, データやユーザー管理をLDAP/ NFS/Sambaによって一元的に管理されている。このネッ トワークでは, 4 本の放射光ビームラインや構造生物学研 究センター関連の研究室と中央サーバーが, 光ファイバー やレイヤー3スイッチで構築された高速ネットワークで 結ばれている.これらの特徴により, どこの拠点にいても 同じ環境でデータ解析, バックアップなどの計算機作業を 行うことができるようになっている.7)

\section{3 自動化と遠隔実験に向けた開発}

ここまで,ビームラインの自動化と遠隔実験に向けて必 要な, ベースとなるビームライン技術について述べてき た.この項目では, 残るピースである, 試料自動位置決め 機能, 回折能判定機能, 実験スケジューリング機能, 遠隔 地からのアクセス技術について, 現在の開発状況を紹介 する.

自動測定において最もカギとなるのは試料位置決めで あろう. 振動写真法において試料をビームから外さずに振 動させるには, 回転軸の中心に試料を正確に位置決めする 必要がある. 試料の位置決めに関して,ループの形状を認 識してビーム位置に駆動する方法は, われわれを含む各所 のシンクロトロンですでに実装されている. 今後は, ルー プ内の結晶試料を認識し, 位置決めする技術が必要にな る. 特に試料サイズが小さくなり, 高輝度ビームラインに なるほどその必要性が増す. SPring-8で開発された試料 交換ロボットでは, 再マウント時の再現性が非常に高くな るよう工夫されており, ピンを一度マウントして測定する 試料の位置をデータベースにあらかじめ登録しておくこ とにより，半自動的に連続測定が実現されている８）われ われは現在, ループ画像を保存しておき, 再マウント時に ループ形状をマッチングさせることで同様の操作が可能 
になる機能を開発中である。また，可視光での試料認識で は, 屈折効果や分解能の問題がありおのずと試料サイズ に限界がある。そのため, X 線ビームを用いて回折強度の 統計值を評価することにより試料の位置決めをする機能 も開発を進めている.最終的には,ループ形状でのラフな 位置決めの後, データベースに記録された位置への半自 動位置決めか，X線ビームを用いた位置決めか，どちらか を選択できるようにする予定である。

試料位置決めが完了したら，次は回折実験である。その 際には, 露光時間や分解能, 測定角度範囲などの実験条件 を決めなければならない. 現在, STARSクライアントの1つ として, PROCESSORクライアントを実装中である.9)こ れは, 回折像から LABELIT10) で結晶方位を決定して結晶 品質を評価し, Mosflm ${ }^{11)}$ で測定範囲や角度を見積もるク ライアントである。この結果から，測定するべきか否かを 判断し，測定する場合には実験条件を自動でセットでき

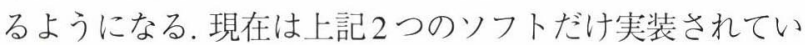
るが, 将来的にはさまざまな処理ソフトに対応し, 測定と 平行してデータ処理が行えるように改良し，ユーザーが ソフトを選択できるようにする予定である。

測定が完了したら，違う試料に載せ換えて次の実験が 開始される. 試料によって, 1 つの実験条件の 1 データセ ットで済む場合や, MAD 法のように 3 波長測定する場合, XAFSにより吸収端測定を行う場合などさまざまである。 そこで, あらかじめどのような実験をするか予定しておく 必要がある.この実験スケジューリング機能は, 上記 PCCS で実現されており，ここまでで一連の自動測定実験が可 能になる、

さて，このように自動測定が可能になると，次のステッ プとして遠隔実験が現実化してくる。そこでわれわれは， STARS 測定システムの拡張として実験モニタリングソフ トを実装し，テスト実験を開始した.9)このソフトは，前述 のPROCESSOR とREPORTER と呼ばれる 2 つの STARS クライアントからなる. PROCESSOR は回折像の品質検 査の結果や，デー夕処理の結果をREPORTERに出力し， REPORTER は実験状況をイベント監視によって情報収集 L, PROCESSORからの結果と合わせてXML 形式で公 開ウェブサーバー上に出力する。これまで述べてきた自 動化のための開発に加えて, この実験モニタリングソフ トを利用することにより，ユーザーはビームラインに来 なくても, 凍結試料がセットされたカセットを搬送デュ ワーで送り，試料や実験に関する必要な情報をビームラ インスタッフに受け渡せば, 回折実験が可能になる。本機 能の実現により移動のコストや時間が省かれ，ユーザー の負担を軽減することができる、特に遠隔地のユーザー にとっては, 本機能の実現に対するリクエストが非常に
大きい.いくつかの施設でも同様の Mail-in サービスが実 現, あるいは予定されているが, フォトンファクトリーで も今秋からテス卜実験を開始し, 来年以降受け入れを開始 したいと考えている.さらにこの次のステップとしては, ビームラインのユーザー遠隔操作化がある. 前述のよう に, STARS 制御システムはネットワーク接続可能な端末 であれば利用可能であるため, 統合 GUI をインストール した遠隔の端末からビームラインの遠隔操作は容易に実 現できる。しかし，ビームラインの安全性やネットワーク セキュリティ,データ保全性など解決しなければならない 問題が多いため今後の課題である.

\section{文 献}

1) A. E. Cohen, P. J. Ellis, M. D. Miller, A. M. Deacon and R. P. Phizackerley: J. Appl. Cryst. 35, 720 (2002).

2) M. Hiraki, S. Watanabe, Y. Yamada, N. Matsugaki, N. Igarashi, Y. Gaponov and S. Wakatsuki: AIP Conf. Proc. 879, 1924 (2007).

3) N. Igarashi, N. Matsugaki, Y. Yamada, M. Hiraki, A. Koyama, K. Hirano, T. Miyoshi and S. Wakatsuki: AIP Conf. Proc. 879, 812 (2007).

4) M. Hiraki, S. Watanabe, N. pHonda, Y. Yamada, N. Matsugaki, N. Igarashi, Y. Gaponov and S. Wakatsuki: J. Synchrotron Rad. submitted.

5) T. Kosuge, Y. Saito, K. Nigorikawa, H. Kawata, A. Shirakawa, H. Nakajima, K. Ito, I. Abe, J. Kishiro and S. Kurokawa: PCaPAC2002 Proceedings, Frascaty, (2002).

6) Y. Gaponov, N. Igarashi, M. Hiraki, K. Sasajima, N. Matsugaki, M. Suzuki, T. Kosuge and S. Wakatsuki: J. Synchrotron Rad. 11, 17 (2004).

7) N. Matsugaki, Y. Yamada, N. Igarashi and S. Wakatsuki: AIP Conf. Proc. 879, 1936 (2007).

8) G. Ueno, R. Hirose, K. Ida, T. Kumasaka and M. Yamamoto: $J$. Appl. Cryst. 37, 867 (2004).

9) Y. Yamada, N. pHonda, N. Matsugaki, N. Igarashi, M. Hiraki and S. Wakatsuki: J. Synchrotron Rad. submitted.

10) A. G. W. Leslie; in Crystallographic Computing, Oxford University Press. (1990).

11) N. K. Sauter, R. W. Grosse-Kunstleve, and P. D. Adams: J. Appl. Cryst. 37, 399 (2004).

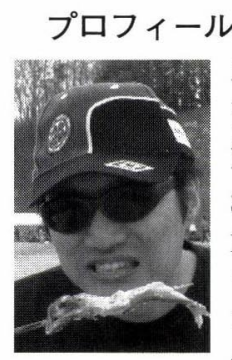

五十嵐教之 Noriyuki IGARASHI 高エネルギー加速器研究機構物質構造科学研究所 放射光科学研究施設構造生物学研究センター

Structural Biology Research Center, Photon Factory, IMSS, KEK

干 305-0801 茨城県つくば市大穗 1-1

1-1 Oho, Tsukuba, Ibaraki 305-0801, Japan e-mail: noriyuki.igarashi@kek.jp

最終学歴：1997年東京工業大学大学院生命理工 学研究科博士課程修了, 博士 (理学) 専門分野: 放射光構造生物学, 蛋白質結晶学 現在の研究テーマ: 放射光構造生物ビームライン の開発をべースとした構造生物学研究の高度化 趣味：スポーツ観戦, アウトドア, 旅行 